\title{
Effect of imazethapyr application timing in kidney and white bean
}

\author{
Nader Soltani ${ }^{*}$, Robert E. Nurse, Peter H. Sikkema
}

University of Guelph Ridgetown Campus, Ridgetown, Canada;

${ }^{*}$ Corresponding Author: soltanin@uoguelph.ca

Received 17 September 2013; revised 1 November 2013; accepted 5 December 2013

Copyright (C) 2013 Nader Soltani et al. This is an open access article distributed under the Creative Commons Attribution License, which permits unrestricted use, distribution, and reproduction in any medium, provided the original work is properly cited.

\section{ABSTRACT}

A total of twelve field trials (6 with kidney bean and 6 with white bean) were conducted over a three-year period (2010 to 2012) at various locations in Ontario to evaluate the tolerance of kidney and white bean to imazethapyr applied preplant incorporated (PPI), preemergence (PRE), and postemergence (POST) at 37.5, 75 and 150 g-ai-ha ${ }^{-1}$. Imazethapyr applied PPI or PRE in kidney or white bean caused $0 \%-1 \%, 0 \%-4 \%$, and $0 \%-9 \%$ injury at 1,2 , and 4 weeks after application (WAA), respectively. However, the injury was transient and had no adverse effect on shoot dry weight, height, seed moisture content, and yield of kidney or white bean except for shoot dry weight which was reduced $32 \%$ with imazethapyr applied PPI compared to the weed free control in white bean. Imazethapyr applied POST in kidney or white bean caused as much as $17 \%, 18 \%$, and $11 \%$ injury at 1,2 , and 4 WAA, respectively. There was no adverse effect on shoot dry weight, height, seed moisture content, and yield of kidney or white bean except for imazethapyr applied POST which increased seed moisture content $1.9 \%$ compared to the weed free control in white bean. Based on these results, there is an adequate margin of crop safety in dry bean to imazethapyr applied PPI or PRE at 37.5 or $75 \mathrm{~g} \cdot \mathrm{ai}^{-\mathrm{ha}^{-1}}$ in kidney and white beans. However, there is not an adequate margin of crop safety for imazethapyr applied POST at rates higher than $37.5 \mathrm{~g} \cdot \mathrm{ai}^{-\mathrm{ha}^{-1}}$ in kidney and white bean.

Keywords: Dry Bean; Phaseolus vulgaris;

Preemergence; Preplant-Incorporated;

Postemergence Herbicides; Sensitivity; Tolerance

\section{INTRODUCTION}

Ontario is one of the leading provinces in Canada in edible bean production and produces 129,000 MT of dry bean with a farm-gate value of approximately $\$ 90$ million [1]. Major market classes of edible bean grown in Ontario include black, cranberry, kidney, and white (navy) bean. Dry bean is more susceptible to yield losses due to weed interference than the other major field crops grown in Ontario. Dry bean seed yield has been reduced an average of $58 \%$ in research studies conducted in Ontario. This is greater than the other major field crops: corn $(52 \%)$, soybean $(40 \%)$, spring cereals $(12 \%)$ and winter wheat $(2 \%)$. In addition, presence of weeds in dry bean at the harvest time can also cause seed staining and interfere with harvesting efficiency [2-6]. In order to be competitive in the global market, dry bean growers need precision weed management strategies that have an adequate margin of crop safety, provide consistent broad spectrum weed control, and maximize seed yield and net returns to dry bean growers. Currently, the only herbicides registered for postemergence (POST) broadleaf weed control in dry bean in Ontario are bentazon and fomesafen [7]. More research is needed to identify herbicides that can provide adequate control of trouble some weeds in dry bean.

Imazethapyr is an imidiazolinone herbicide, which is absorbed by both roots and shoots and can be applied preplant incorporated (PPI), preemergence (PRE) and postemergence (POST). Imazethapyr can control annual broadleaf and grass weeds including Abutilon theophrasti (velvetleaf), Amaranthus retroflexus (redroot pigweed), Chenopodium album (common lambsquarters), Sinapis arvensis (wild mustard), Ambrosia artemesiifolia (common ragweed), Solanum ptycanthum (Eastern black nightshade), Polygonum convolvulus (wild buckwheat) and other Polygonum spp. [2,3,6-8].

To our knowledge, there has been no study that compares the effect of imazethapyr application timing (PPI, 
PRE or POST) in kidney and white bean under Ontario environmental conditions. The objective of this research was to evaluate the effect of imazethapyr applied PPI, PRE and POST in kidney and white bean under Ontario environmental conditions.

\section{MATERIALS AND METHODS}

Field studies were conducted at the Huron Research Station, Exeter, Ontario in 2011 to 2012; at the Agriculture and Agri-Food Canada Research Centre, Harrow, Ontario in 2012; and University of Guelph, Ridgetown Campus, Ridgetown, Ontario in 2010 to 2012. The soil at Exeter was a Brookston clay loam (Orthic Humic Gleysol). The soil at Ridgetown was a Watford (Grey to Brown Brunisolic)-Brady (Gleyed Brunisolic Grey to Brown Luvisol, mixed) sandy loam. The soil at Harrow was a Fox sandy loam (Brunisolic Gray Brown Luvisol). Seedbed preparation at all sites consisted of fall moldboard plowing followed by two passes with a field cultivator in the spring.

The experiments were arranged in a split-plot design with four replications for kidney and white beans separately adjacent to each other ( 6 with kidney bean and 6 with white bean). The main plots were application timing (PPI, PRE, and POST). The sub-plots were imazethapyr rates (37.5, 75 and $\left.150 \mathrm{~g} \cdot \mathrm{ha}^{-1}\right)$. Kidney bean "Red Hawk" was planted at a rate of 175,000 seeds $\cdot \mathrm{ha}^{-1}$ and white bean "T9905" was planted at a rate of 230,000 seeds $\cdot \mathrm{ha}^{-1}$ to a depth of $5 \mathrm{~cm}$ in rows that were spaced $0.75 \mathrm{~m}$ apart and were 8 or $10 \mathrm{~m}$ long in late May to early June of each year.

Herbicide treatments were applied using a $\mathrm{CO}_{2}$-pressurized backpack sprayer calibrated to deliver $200 \mathrm{~L} \cdot \mathrm{ha}^{-1}$ at $241 \mathrm{kPa}$ at Exeter, at $210 \mathrm{kPa}$ at Harrow, and $200 \mathrm{kPa}$ at Ridgetown. PPI, PRE, and POST [included nonionic surfactant Agral 90 at $0.25 \mathrm{v} / \mathrm{v}$ and Urea Ammonium Nitrate (UAN) at $\left.2 \mathrm{~L} \cdot \mathrm{ha}^{-1}\right]$ herbicides were applied 1 - 2 days before planting (incorporated immediately), 1 - 2 days after planting, and 3 - 4 wks after planting (2 - 3 trifoliate leaf stage), respectively. All plots were maintained weed-free with inter-row cultivation and hand hoeing during the growing season.

Visual estimates of crop injury were evaluated 1, 2, and 4 weeks after herbicide application (WAA) on a scale of 0 to $100 \%(0 \%=$ no injury and $100 \%=$ plant death). A $1 \mathrm{~m}$ section of bean row was hand harvested from each plot at 4 WAA and dried to constant moisture at $60^{\circ} \mathrm{C}$ and the shoot dry weight was recorded. Ten plants from each plot were randomly selected and the height from the soil surface to the highest growing point was measured at 6 WAA. Yield was measured at crop maturity by hand harvesting $9 \mathrm{~m}$ from each plot at Exeter, $7 \mathrm{~m}$ from each plot at Harrow, and $7 \mathrm{~m}$ from each plot at Ridgetown in late September to early October. Seed moisture content at harvest was measured for each plot to determine if there was a delay in dry bean maturity. Yields were adjusted to $18 \%$ moisture.

All data were analyzed using analysis of variance (ANOVA). Data were analyzed using the PROC MIXED procedure of Statistical Analysis Systems. Variances were partitioned into the random effects of locations, years, years by locations, blocks within years by locations, and their interactions with fixed effects (herbicide rates, application timings). Significance of random effects was tested using a Z-test of the variance estimate and fixed effects were tested using F-tests. Error assumptions of the variance analyses (random, homogeneous, normal distribution of error) were confirmed using residual plots and the Shapiro-Wilk normality test. To meet the assumptions of the variance analysis, percent injury data at 1, 2 and 4 WAA and dry weight data were subjected to an arcsine square root transformation. Percent injury and dry weight means were compared on the transformed scale and were converted back to the original scale for presentation of results. The distribution of plant height, seed moisture and yield data were not improved by data transformation. Treatment means were separated using Fisher's protected LSD. The Type I error was set at 0.05 for all statistical comparisons.

\section{RESULTS AND DISCUSSION}

Statistical analysis of data indicated that for kidney or white bean trials environment by application timing by rate interactions were not significant for injury ratings, shoot dry weight, height, seed moisture content and seed yield, therefore all environments were analyzed together for kidney and white bean (Tables 1 and 2).

\subsection{Crop Injury}

Crop injury symptoms with imazethapyr included chlorosis of leaves, necrosis of leaves and stunting of dry bean. Growth reduction was much faster with POST application. Imazethapyr applied PPI or PRE at 37.5, 75, and $150 \mathrm{~g} \cdot$ ai $^{\circ} \mathrm{ha}^{-1}$ caused no visible injury at $1 \mathrm{WAA}, 2 \%$ or less injury at 2 WAA and $5 \%$ or less injury at 4 WAA in kidney bean (Table 1). Injury was significantly greater with imazethapyr applied POST at 1, 2, and 4 WAA (Table 1). Imazethapyr applied POST caused $6 \%-17 \%$ injury at 1 WAA, $3 \%-18 \%$ injury at 2 WAA, and $3 \%$ $11 \%$ injury at 4 WAA in kidney bean (Table 1). Kidney bean injury generally increased as the imazethapyr POST rate was increased; however, differences were not always statistically significant (Table 1).

Imazethapyr applied PPI or PRE at 37.5, 75, and 150 $\mathrm{g} \cdot \mathrm{ai} \cdot \mathrm{ha}^{-1}$ caused $1 \%$ or less injury at $1 \mathrm{WAA}, 4 \%$ or less injury at 2 WAA and $9 \%$ or less injury at 4 WAA in white bean (Table 2). Injury was significantly greater with 
Table 1. Percent injury 1, 2, and 4 WAA, shoot dry weight, height, seed moisture content, and yield of kidney bean treated with various treatments at Ridgetown in 2010-2012; Exeter in 2011-2012; and Harrow in 2012. Means followed by the same letter within a column (a-c) are not significantly different according to Fisher's Protected LSD at $\mathrm{P}<0.05^{\mathrm{ab}}$.

\begin{tabular}{|c|c|c|c|c|c|c|c|c|c|}
\hline \multirow[t]{2}{*}{ Treatment } & \multirow[t]{2}{*}{ Timing } & \multirow{2}{*}{$\begin{array}{c}\text { Rate } \\
\mathrm{g} \cdot \mathrm{ai}^{-} \mathrm{ha}^{-1}\end{array}$} & \multicolumn{3}{|c|}{ Injury $(\%)$} & \multirow{2}{*}{$\begin{array}{c}\text { Weight } \\
\mathrm{g} \cdot \mathrm{m}^{- \text {row }^{-1}}\end{array}$} & \multirow{2}{*}{$\begin{array}{c}\text { Height } \\
\mathrm{cm}\end{array}$} & \multirow{2}{*}{$\begin{array}{c}\text { Seed Moisture } \\
\%\end{array}$} & \multirow{2}{*}{$\begin{array}{c}\text { Yield } \\
\text { MT } \cdot \text { ha }^{-1}\end{array}$} \\
\hline & & & $1 \mathrm{WAA}$ & 2 WAA & 4 WAA & & & & \\
\hline Weed Free Control & & & $0^{\mathrm{c}}$ & $0^{\mathrm{c}}$ & $0^{\mathrm{a}}$ & $71.5^{\mathrm{a}}$ & $60.2^{\mathrm{a}}$ & $18.0^{\mathrm{ab}}$ & $2.0^{\mathrm{a}}$ \\
\hline Imazethapyr & PPI & 37.5 & $0^{\mathrm{c}}$ & $0^{\mathrm{c}}$ & $0^{\mathrm{a}}$ & $69.6^{\mathrm{a}}$ & $59.7^{\mathrm{a}}$ & $17.4^{\mathrm{b}}$ & $2.0^{\mathrm{a}}$ \\
\hline Imazethapyr & PPI & 75 & $0^{\mathrm{c}}$ & $1^{\mathrm{c}}$ & $2^{\mathrm{a}}$ & $71.5^{\mathrm{a}}$ & $59.7^{\mathrm{a}}$ & $17.7^{\mathrm{ab}}$ & $1.9^{\mathrm{a}}$ \\
\hline Imazethapyr & PPI & 150 & $0^{\mathrm{c}}$ & $2^{\mathrm{c}}$ & $4^{\mathrm{a}}$ & $72.2^{\mathrm{a}}$ & $59.1^{\mathrm{a}}$ & $17.9^{\mathrm{ab}}$ & $1.9^{\mathrm{a}}$ \\
\hline Imazethapyr & PRE & 37.5 & $0^{\mathrm{c}}$ & $1^{\mathrm{c}}$ & $1^{\mathrm{a}}$ & $69.6^{\mathrm{a}}$ & $60.6^{\mathrm{a}}$ & $17.7^{\mathrm{ab}}$ & $1.9^{\mathrm{a}}$ \\
\hline Imazethapyr & PRE & 75 & $0^{\mathrm{c}}$ & $1^{\mathrm{c}}$ & $2^{\mathrm{a}}$ & $65.8^{\mathrm{a}}$ & $58.8^{\mathrm{a}}$ & $17.4^{\mathrm{b}}$ & $2.0^{\mathrm{a}}$ \\
\hline Imazethapyr & PRE & 150 & $0^{\mathrm{c}}$ & $3^{\mathrm{bc}}$ & $5^{\mathrm{a}}$ & $62.1^{\mathrm{a}}$ & $58.2^{\mathrm{a}}$ & $17.8^{\mathrm{ab}}$ & $1.9^{\mathrm{a}}$ \\
\hline Imazethapyr + Agral $90+$ UAN 28\% & POST & 37.5 & $6^{\mathrm{bc}}$ & $3^{\mathrm{bc}}$ & $3^{\mathrm{a}}$ & $69.3^{\mathrm{a}}$ & $60.2^{\mathrm{a}}$ & $17.5^{\mathrm{ab}}$ & $2.0^{\mathrm{a}}$ \\
\hline Imazethapyr + Agral $90+$ UAN 28\% & POST & 75 & $11^{\mathrm{b}}$ & $9^{b}$ & $6^{\mathrm{a}}$ & $66.1^{\mathrm{a}}$ & $60.8^{\mathrm{a}}$ & $18.0^{\mathrm{ab}}$ & $1.9^{\mathrm{a}}$ \\
\hline Imazethapyr + Agral $90+$ UAN 28\% & POST & 150 & $17^{\mathrm{a}}$ & $18^{\mathrm{a}}$ & $11^{\mathrm{a}}$ & $61.2^{\mathrm{a}}$ & $60.0^{\mathrm{a}}$ & $18.2^{\mathrm{a}}$ & $1.8^{\mathrm{a}}$ \\
\hline $\mathrm{LSD}_{0.05}$ & & & 5.6 & 6.9 & 11.6 & 20.0 & 6.8 & 0.7 & 0.3 \\
\hline
\end{tabular}

${ }^{\mathrm{a}}$ Abbreviations: WAA, week after herbicide application; POST, postemergence; PPI, preplant incorporated; PRE, preemergence. ${ }^{\mathrm{b}}$ Postemergence treatments included Agral 90 (non-ionic surfactant; nonylphenoxy polyethyoxyethanol 90\%) and UAN (Urea Ammonium Nitrate) $28 \%$ applied at $0.25 \% \mathrm{v} / \mathrm{v}$ and 2 L·ha ${ }^{-1}$, respectively. ${ }^{\mathrm{c}}$ Data have been pooled and averaged over environments.

Table 2. Percent injury 1, 2, and 4 WAA, shoot dry weight, height, seed moisture content, and yield of white bean treated with various treatments at Ridgetown in 2010-2012; Exeter in 2011-2012; and Harrow in 2012. Means followed by the same letter within a column (a-c) are not significantly different according to Fisher's Protected LSD at $\mathrm{P}<0.05^{\mathrm{abc}}$.

\begin{tabular}{|c|c|c|c|c|c|c|c|c|c|}
\hline \multirow[t]{2}{*}{ Treatment } & \multirow[t]{2}{*}{ Timing } & \multirow{2}{*}{$\frac{\text { Rate }}{\mathrm{g} \cdot \mathrm{ai}^{\circ} \mathrm{ha}^{-1}}$} & \multicolumn{3}{|c|}{ Injury $(\%)$} & \multirow{2}{*}{$\begin{array}{c}\text { Weight } \\
\mathrm{g} \cdot \mathrm{m}^{- \text {row }^{-1}}\end{array}$} & \multirow{2}{*}{$\begin{array}{c}\text { Height } \\
\mathrm{cm}\end{array}$} & \multirow{2}{*}{$\begin{array}{c}\text { Seed Moisture } \\
\%\end{array}$} & \multirow{2}{*}{$\begin{array}{c}\text { Yield } \\
\text { MT }^{\text {ha }}{ }^{-1}\end{array}$} \\
\hline & & & $1 \mathrm{WAA}$ & 2 WAA & 4 WAA & & & & \\
\hline Weed Free Control & & & $0^{c}$ & $0^{c}$ & $0^{\mathrm{a}}$ & $64.9^{\mathrm{a}}$ & $62.8^{\mathrm{a}}$ & $17.8^{\mathrm{b}}$ & $3.5^{\mathrm{a}}$ \\
\hline Imazethapyr & PPI & 37.5 & $0^{\mathrm{c}}$ & $0^{\mathrm{c}}$ & $0^{\mathrm{a}}$ & $60.1^{\mathrm{ab}}$ & $63.4^{\mathrm{a}}$ & $17.6^{\mathrm{b}}$ & $3.5^{\mathrm{a}}$ \\
\hline Imazethapyr & PPI & 75 & $0^{\mathrm{c}}$ & $1^{\mathrm{c}}$ & $4^{\mathrm{a}}$ & $54.0^{\mathrm{ab}}$ & $62.9^{\mathrm{a}}$ & $17.8^{\mathrm{b}}$ & $3.4^{\mathrm{a}}$ \\
\hline Imazethapyr & PPI & 150 & $1^{\mathrm{c}}$ & $3^{\mathrm{bc}}$ & $8^{\mathrm{a}}$ & $44.1^{b}$ & $58.7^{\mathrm{a}}$ & $18.0^{\mathrm{b}}$ & $3.1^{\mathrm{a}}$ \\
\hline Imazethapyr & PRE & 37.5 & $0^{\mathrm{c}}$ & $1^{\mathrm{c}}$ & $1^{\mathrm{a}}$ & $58.2^{\mathrm{ab}}$ & $63.5^{\mathrm{a}}$ & $17.2^{\mathrm{b}}$ & $3.6^{\mathrm{a}}$ \\
\hline Imazethapyr & PRE & 150 & $1^{\mathrm{c}}$ & $4^{\mathrm{bc}}$ & $9^{\mathrm{a}}$ & $55.6^{\mathrm{ab}}$ & $57.9^{\mathrm{a}}$ & $17.5^{\mathrm{b}}$ & $3.0^{\mathrm{a}}$ \\
\hline Imazethapyr + Agral $90+$ UAN 28\% & POST & 37.5 & $5^{\mathrm{bc}}$ & $3^{\mathrm{bc}}$ & $2^{\mathrm{a}}$ & $60.8^{\mathrm{ab}}$ & $63.3^{\mathrm{a}}$ & $17.5^{\mathrm{b}}$ & $3.5^{\mathrm{a}}$ \\
\hline Imazethapyr + Agral $90+$ UAN 28\% & POST & 75 & $9^{\mathrm{b}}$ & $9^{b}$ & $6^{\mathrm{a}}$ & $58.0^{\mathrm{ab}}$ & $63.1^{\mathrm{a}}$ & $18.3^{\mathrm{b}}$ & $3.4^{\mathrm{a}}$ \\
\hline Imazethapyr + Agral $90+$ UAN 28\% & POST & 150 & $14^{\mathrm{a}}$ & $17^{\mathrm{a}}$ & $11^{\mathrm{a}}$ & $51.1^{\mathrm{ab}}$ & $62.2^{\mathrm{a}}$ & $19.7^{\mathrm{a}}$ & $3.2^{\mathrm{a}}$ \\
\hline $\operatorname{LSD}_{0.05}$ & & & 5.3 & 6.3 & 13.5 & 19.6 & 5.9 & 1.1 & 0.6 \\
\hline
\end{tabular}

${ }^{a}$ Abbreviations: WAA, week after herbicide application; POST, postemergence; PPI, preplant incorporated; PRE, preemergence. ${ }^{b}$ Postemergence treatments included Agral 90 (non-ionic surfactant; nonylphenoxy polyethyoxyethanol 90\%) and UAN (Urea Ammonium Nitrate) $28 \%$ applied at $0.25 \%$ v/v and 2 L·ha ${ }^{-1}$, respectively. ${ }^{c}$ Data have been pooled and averaged over environments.

imazethapyr applied POST at 1, 2, and 4 WAA (Table 2). Imazethapyr applied POST at 37.5, 75, and $150 \mathrm{~g} \cdot \mathrm{ai} \cdot \mathrm{ha}^{-1}$ caused 5\% - 14\% injury at 1 WAA, $3 \%-17 \%$ injury at 2 WAA, and $2 \%-11 \%$ injury at 4 WAA in white bean (Table 2). White bean injury generally increased as the imazethapyr POST rate was increased; however, differences were not always statistically significant (Table 2).

Crop injury in this study with imazethapyr applied PPI and PRE is similar to those reported by Arnold et al. [2] that found less than 7\% injury in dry bean. In other studies conducted in New Mexico and Alberta, imazethapyr applied POST at 50 and $70 \mathrm{~g} \cdot \mathrm{ai} \cdot \mathrm{ha}^{-1}$ had adequate tolerance in pinto bean $[2,4]$. However, other studies conducted at Michigan, Nebraska, and Wyoming imazethapyr applied POST at 70 to $100 \mathrm{~g} \cdot \mathrm{ai}^{\mathrm{h}} \mathrm{ha}^{-1}$ caused up to $20 \%$ injury in dry bean [3,6]. Renner and Powell [9] reported that imazethapyr applied POST caused 20\% injury in pinto bean. Other studies found as much as $44 \%$ injury in pinto and SRM bean with imazethapyr [10].

\subsection{Shoot Dry Weight}

Imazethapyr applied PPI, PRE, and POST at 37.5, 75, and $150 \mathrm{~g} \cdot \mathrm{ai} \cdot \mathrm{ha}^{-1}$ caused no adverse effect on shoot dry weight of kidney bean (Table 1). Imazethapyr applied PPI, PRE, and POST at 37.5, 75, and $150 \mathrm{~g} \cdot \mathrm{ai} \cdot \mathrm{ha}^{-1}$ also caused no adverse effect on shoot dry weight of white bean except when applied PPI at $150 \mathrm{~g} \cdot \mathrm{ai} \cdot \mathrm{ha}^{-1}$ which decreased shoot dry weight $32 \%$ compared to the weed free control (Tables 2).

In other studies, the PPI and PRE applications of imazethapyr at $75 \mathrm{~g} \cdot \mathrm{ai} \cdot \mathrm{ha}^{-1}$ did not caused any adverse effect on shoot dry weight of cranberry bean but when 
applied PPI at $150 \mathrm{~g} \cdot \mathrm{ai} \cdot \mathrm{ha}^{-1}$ reduced shoot dry weight $16 \%$ [11]. Blackshaw and Saindon [12] reported as much as $29 \%$ shoot dry weight reduction with POST applications of imazethapyr in dry bean. Other studies reported as much as 34\% reduction in shoot dry weight with POST application of imazethapyr in dry bean [11].

\subsection{Plant Height}

Plant height is critical to dry bean growers as shorter plants increase bean shatter losses at the cutter bar of the combine. Generally, dry bean growers do not like to see any decrease in plant height. Imazethapyr applied PPI, PRE, and POST at 37.5, 75, and $150 \mathrm{~g} \cdot \mathrm{ai}^{\circ} \cdot \mathrm{ha}^{-1}$ caused no decrease in plant height of kidney or white bean compared to the weed free control (Tables 1 and 2).

In other studies, the PPI and PRE applications of imazethapyr at $75 \mathrm{~g} \cdot \mathrm{ai} \cdot \mathrm{ha}^{-1}$ did not cause any adverse effect on shoot dry weight of cranberry bean but when applied PPI at $150 \mathrm{~g} \cdot \mathrm{ai}^{-\mathrm{ha}^{-1}}$ reduced height $7 \%$ [11]. Imazethapyr POST has been reported to reduce plant height as much as $21 \%$ in dry bean [10]. Imazamox has also been reported to reduce dry bean height by 5 to $8 \mathrm{~cm}$ [13].

\subsection{Seed Moisture Content and Yield}

Seed moisture content is important in dry bean production as more moisture at time of harvest might be an indication of delayed maturity caused by herbicide. Higher seed moisture content at harvest can also increase spoilage due to bacterial and fungal diseases, staining, or increased drying costs, and can result in dockage at the point of sale. Imazethapyr applied PPI, PRE, and POST at $37.5,75$, and $150 \mathrm{~g} \cdot \mathrm{ai} \cdot \mathrm{ha}^{-1}$ caused no adverse effect on seed moisture content of kidney or white bean except when applied POST at $150 \mathrm{~g} \cdot \mathrm{ai} \cdot \mathrm{ha}^{-1}$ which increased seed moisture content $1.9 \%$ compared to the weed free control (Tables 1 and 2).

Seed yield ranged between 1.8 to $2.0 \mathrm{t} \cdot \mathrm{ha}^{-1}$ in kidney bean and 3.0 to $3.5 \mathrm{t} \cdot \mathrm{ha}^{-1}$ in white bean with treatments evaluated (Tables 1 and 2). Imazethapyr applied PPI, PRE, and POST at 37.5, 75, and $150 \mathrm{~g} \cdot \mathrm{ai}^{\cdot} \mathrm{ha}^{-1}$ caused no adverse effect on seed yield of kidney or white bean compared to the weed free control (Tables 1 and 2).

In other studies, imazethapyr applied PPI or PRE at 75 or $150 \mathrm{~g} \cdot \mathrm{ai} \cdot \mathrm{ha}^{-1}$ did not cause any adverse effect on seed moisture content and seed yield of cranberry bean [11]. Other researchers have reported varying seed moisture and yield responses with imazethapyr in dry bean [2,3]. Arnold et al. [2] found no yield reduction with imazethapyr POST at 50 and $70 \mathrm{~g} \cdot \mathrm{ai} \cdot \mathrm{ha}^{-1}$ in pinto bean. Bauer et al. [3] reported that imazethapyr at $53 \mathrm{~g} \cdot \mathrm{ai} \cdot \mathrm{ha}^{-1}$ applied POST delayed maturity but did not affect yield; however, imazethapyr at $106 \mathrm{~g} \cdot \mathrm{ai}^{\circ} \mathrm{ha}^{-1}$ reduced yield of some mar- ket classes of dry bean. Blackshaw and Saindon [12] found as much as $25 \%$ yield reduction in dry bean with imazethapyr POST at $200 \mathrm{~g} \cdot \mathrm{ai} \cdot \mathrm{ha}^{-1}$. They also found that maturity of dry bean was delayed with imazethapyr POST at 100 and $200 \mathrm{~g} \cdot \mathrm{ai} \cdot \mathrm{ha}^{-1}$. Imazethapyr applied POST also reduced dry bean yield as much as $16 \%$ and increased seed moisture content of dry bean as much as $3 \%[10]$.

\section{CONCLUSION}

Imazethapyr applied PPI or PRE at 37.5 or $75 \mathrm{~g} \cdot \mathrm{ai}^{\circ} \mathrm{ha}^{-1}$ and applied POST at $37.5 \mathrm{~g} \cdot \mathrm{ai}^{\circ} \mathrm{ha}^{-1}$ caused minimal injury ( $6 \%$ or less) in kidney and white bean but the injury was transient and had no adverse effect on shoot dry weight, height, seed moisture content, and yield of kidney or white bean. However, imazethapyr applied PPI or PRE at $150 \mathrm{~g} \cdot \mathrm{ai}^{-\mathrm{ha}^{-1}}$ and applied POST at 70 or 150 $\mathrm{g} \cdot \mathrm{ai} \cdot \mathrm{ha}^{-1}$ has the potential to cause significant injury in kidney and white bean under Ontario environmental conditions. Based on these results, there is an adequate margin of crop safety in dry bean to imazethapyr applied PPI or PRE at 37.5 or $75 \mathrm{~g} \cdot \mathrm{ai} \cdot \mathrm{ha}^{-1}$ in kidney and white bean. However, there is not an adequate margin of crop safety for imazethapyr applied POST at rates higher than 37.5 $\mathrm{g} \cdot \mathrm{ai} \cdot \mathrm{ha}^{-1}$ in kidney and white bean.

\section{ACKNOWLEDGEMENTS}

The authors acknowledge Todd Cowan, Elaine Lepp and Christy Shropshire for their expertise and technical assistance in these studies. Funding for this project was provided by the Ontario White Bean Producers, Ontario Coloured Bean Growers Association, the Pest Management Centre of Agriculture and Agri-Food Canada, and the Agricultural Adaptation Council.

\section{REFERENCES}

[1] Kulasekera, K. (2013) Estimated area, yield, production and farm value of specified field crops, Ontario, 20012012. Metric Units.

http://www.omafra.gov.on.ca/english/stats/crops/estimate metric.htm

[2] Arnold, N.R., Murray, W.M., Gregory, J.E. and Smeal, D. (1993) Weed control in pinto beans (Phaseolus vulgaris) with imazethapyr combinations. Weed Technology, 7, 361364.

[3] Bauer, T.A., Renner, K.A., Penner, D. and Kelly J.D. (1995) Pinto bean (Phaseolus vulgaris) varietal tolerance to imazethapyr. Weed Science, 43, 417-424.

[4] Blackshaw, R.E. and Esau, R. (1991) Control of annual broadleaved weeds in pinto beans (Phaseolus vulgaris). Weed Technology, 5, 532-538.

[5] Urwin, C.P., Wilson, R.G. and Mortensen, D.A. (1996) Responses of dry edible bean (Phaseolus vulgaris) cultivars to four herbicides. Weed Technology, 10, 512-518. 
[6] Wilson, R.G. and Miller, S.D. (1991) Dry edible bean (Phaseolus vulgaris) responses to imazethapyr. Weed Technology, 5, 22-26.

[7] Ontario Ministry of Agriculture, Food, and Rural Affairs (2012) Guide to weed control. Publication 75. Ontario Ministry of Agriculture, Food, and Rural Affairs, Toronto.

[8] Senseman, S.A. (2007) Herbicide handbook. 9th Edition, Weed Science Society of America, Champaign, 458 pp.

[9] Renner, K.A. and Powell, G.E. (1992) Responses of navy bean (Phaseolus vulgaris) and wheat (Triticum aestivum) grown in rotation to clomazone, imazethapyr, bentazon, and acifluorfen. Weed Science, 40, 127-133.

[10] Soltani, N., Nurse, R.E., Robinson, D.E. and Sikkema, P.H. (2008) Response of pinto and Small Red Mexican bean to postemergence herbicides. Weed Technology, 22, 195-199. http://dx.doi.org/10.1614/WT-07-091.1
[11] Soltani, N., Shropshire, C., Cowan, T. and Sikkema, P.H. (2003) Tolerance of cranberry beans (Phaseolus vulgaris) to soil applications of $S$-metolachlor and imazethapyr. Canadian Journal of Plant Science, 83, 645-648. http://dx.doi.org/10.4141/P03-006

[12] Blackshaw, R.E. and Saindon, G. (1996) Dry bean (Phaseolus vulgaris) tolerance to imazethapyr. Canadian Journal of Plant Science, 76, 915-919. http://dx.doi.org/10.4141/cips96-153

[13] Blackshaw, R.E., Molnar, L.J., Muendel, H.H., Saindon, G. and Li, X. (2000) Integration of cropping practices and herbicide improves weed management in dry bean (Phaseolus vulgaris). Weed Technology, 14, 327-336.

http://dx.doi.org/10.1614/0890-037X(2000)014[0327:IO CPAH]2.0.CO;2

\section{ABBREVIATIONS}

PRE: Preemergence;

POST: Postemergence;

WAA: Weeks after herbicide application. 